\title{
Service quality in the banking sector: the impact of technology on service delivery
}

\author{
Mathew Joseph \\ Associate Professor of Marketing, School of Business, Georgia College \& State \\ University, Georgia, USA \\ Cindy McClure \\ Graduate in Marketing, School of Business, Swinburne University, Melbourne, \\ Victoria, Australia \\ Beatriz Joseph \\ Lecturer in Marketing, School of Business, Georgia College \& State University, \\ Georgia, USA
}

\section{Keywords \\ Banking, New technology, \\ Service quality, \\ Customer satisfaction, Australia}

\section{Abstract}

The use of technology in the delivery of banking services is becoming increasingly prevalent as it is being employed to reduce costs and eliminate uncertainties. This research investigates the role that technology plays in Australian banking and its impact on the delivery of perceived service quality. A sample of 440 electronic banking customers was taken and 300 useable questionnaires were analysed. Using the Hemmasi et al. importance-performance grid, results indicated that consumers have perceptual problems with some aspects of electronic bank ing. Some strategic implications are discussed.

International Journal of Bank

Marketing

17/4 [1999] 182-191

(C) MCB University Press

[ISSN 0265-2323]

\section{Introduction}

Over the past 15 years technology has increasingly been employed in the delivery of services. The adoption of technology into service industries is becoming a strong trend as service providers are now being urged by industry bodies to invest in technology (Australian Coalition of Services Industries Annual Review, 1997a; 1997b) as a way of securing their future in the electronic age.

The role of technology in service organisations as discussed by Kelley (1989) has been predominantly employed to reduce costs and eliminate uncertainties. In the service sector, technology has been used to standardise services by reducing the employee/customer interface (Quinn, 1996). The majority of consumers are now more than ever preferring to opt for a technology-based service delivery over that of the employee (Voice + The European Magazine for Applications of Computer Telephony, 1997). This emerging trend raises some important issues about the impact that technology will have on service quality and customer satisfaction levels. To what extent can the employee/customer interface be removed from the front line and still maintain or improve the levels of customer satisfaction? Dabholkar (1996) suggests that little is known about consumer preference for self-service options, particularly those that are technological based. Furthermore Cowels and Crosby (1990) have researched tolerance levels of consumers' preferences for using technology instead of the human touch.

The growth of technology in the delivery of services has had a dramatic effect on the nature of the core offering. Gilbert (1997) uses an analogy to make it simpler to understand the "revolution" that has taken place in technological development in the past two

The current issue and full text archive of this journal is available at http://www.emerald-library.com decades. If technology (in terms of development, pricing and accessibility improvements) had occurred in the transport industry over the same period of time (19751997) as the computer, an aircraft that cost AU $\$ 10$ million in 1975 would now cost AU $\$ 450$.

The nature of service organisations has changed over the past two decades. This change has been influenced by the development of storage and speed of data transfer, particularly in electronic funds transfer known as EFTPOS. Whole new industries have emerged (Bradley, 1993), including news retrieval services and video conferencing.

Dabholkar (1994) discusses how technology-based services have made new service delivery options available to organisations, making customer participation more widely possible. Customers use touch screen "kiosks" to order take-away food, whilst banks have widely distributed automatic teller machines to withdraw, transfer funds or make deposits into accounts.

Accessibility has been extended through technological developments as well as the introduction of new service delivery methods that allow consumers to do business with service firms from the home and office.

\section{Impact of technology on the banking sector}

In the categorisation of services in technology-based service delivery options Dabholkar (1994) suggests there are a number of relevant classifications that will apply to industries employing technology based service delivery. The classification analyses "who" delivers the service. That is, person to person, where the employee uses the technology or consumer to technology, such as the use of an ATM. The next categorisation looks at where the service is delivered. Either on the service firm's sites themself, at the customer's home or office or at a "neutral" site such as an ATM located at an airport. The final categorisation 
Mathew Joseph,

Cindy McClure and

Beatriz Joseph

Service quality in the banking

sector: the impact of

technology on service delivery

International Journal of Bank

Marketing

17/4 [1999] 182-191 looks at the contact the customer has with the service operation, either direct or indirect such as in the case of telephone banking.

Dabholkar (1994) claims that when the customer is in direct contact with the technology there is greater control such as with Internet banking. However, if there is an absence of direct contact, such as with telephone banking (since the technology itself is not visible to customers who are able only to press numbers on their telephone keypad) it is assumed that there is less control perceived by the customer during this transaction. Bateson (1984) has conducted a number of studies on the need for consumers to have control during service encounters. When a consumer freely chooses to use technology as a form of service delivery the impact is high in terms of quality attributes. Some of the quality attributes that are highly important to consumers are efficiency and speed (Bateson, 1984). This concept is supported by Weatherall et al. (1984), who state that consumers are thought to have a positive perception of technology based service attributes since they believe technology will deliver a faster and more efficient service than that of the employee. Gummesson (1991) also stresses that reliability and user-friendliness are important attributes in the evaluation of technologybased services.

Dabholkar (1994) stipulates that there should be flexibility in the design of the technology to allow customers to make changes during the transaction and make available a customer service adviser if required, with "minimum waiting". This also raises the design issue of sufficient menu options for ATM/Telephone and Internet bankers. In most eases the transaction occurs in a neutral location and the availability of an employee may not always be feasible since these facilities often operate 24 hours a day, seven days a week.

\section{Banking in Australia}

Since the deregulation of the financial services sector in Australia in 1984 banking has seen a number of significant changes, including the restructuring and redesigning of the service delivery methods offered. The merging of banks in Australia has created the "Big Four" (the ANZ, Commonwealth Bank of Australia, National Australia Bank, Westpac). This has led to branch closures and staff cuts as banking executives had to capitalise on the economies of scale, which has resulted in a number of dissatisfied and hostile customers. Australian banks seem to be following in the footsteps of the "Big Four" in the UK (Barclays, Lloyds, Midland and National Westminster) which according to Choice Magazine (1998a; 1998b) have been criticised for their unresponsiveness, highly bureaucratic structures and increasing fees.

The implementation of technology-based service delivery options has seen the successful introduction and adoption of telephone-based services which require the customer to use the telephone keypad to interact with a voice-activated computer (Choice Magazine, 1998a; 1998b) and over 11,000 ATMs and 200,000 EFTPOS outlets implemented throughout Australia (Choice Magazine, 1998a; 1998b). At the same time customer satisfaction levels are at an all time low, dragging the bank's image, credibility and staff morale down. It is with these issues in mind that this study aims to define the underlying processes that consumers view as important in electronic banking and to analyse how electronic banking providers are performing to these factors.

\section{Service quality using importance-performance measurement}

When customers evaluate the quality of the service they receive from a banking institution they use different criteria which are likely to differ in their importance, usually some being more important than others. While several criteria are important only a few are most important. These determinant attributes are the ones that will define service quality from the consumer's perspective (Loudon and Della Bitta, 1988). However, many established models of service quality have tended to focus on expectations and marginalise the issue of importance.

Thus, for example, of the most widely used model to measure perceived service quality was developed by Parasuraman et al. (1985; 1988). This conceptual model indicated that customers' perception of service quality was influenced by a series of (expectations-performance) gaps that hinder the delivery of high service quality. This disconfirmationbased model has been the object of some major criticisms, including ambiguity in the definition of expectations and its applicability to a variety of industries (Teas, 1993, 1994; Cronin and Taylor, 1992, 1994). Another weakness of this model is that for it to function correctly, expectations must remain constant. However, Carman (1990) maintains that expectations change with familiarity with the service. Finally, the framework does not explicitly consider the relative 
Mathew Joseph,

Cindy McClure and

Beatriz Joseph

Service quality in the banking

sector: the impact of

technology on service delivery

International Journal of Bank

Marketing

17/4 [1999] 182-191 importance of different attributes of service (although it may be that expectations serve as some kind of proxy for importance - at least in terms of decisions regarding the management of service quality). Because of its impact on consumer decision making, the explicit consideration of importance in service quality may provide additional useful insights.

Martilia and James (1977) developed a simple importance/performance technique whose most attractive feature is that the mean importance and performance results can be graphically illustrated on a two dimensional grid. The four quadrants in the grid can provide in-depth information on each of the attributes tested. According to Ortinau et al. (1989), each of the quadrants can be described as follows:

- Concentrate here: This is where customers feel that a specific attribute is very important but its performance is not satisfactory.

- Keep up the good work: is where customers feel that a specific attribute is very important and are satisfied with its performance.

- Low priority: where customers are not satisfied with the performance of a specific attribute but they do not perceive it as being important.

- Possible overkill: customers are satisfied with the performance of a specific attribute but the customers do not perceive it as being important.

Martilia and James (1977) state that several issues must be dealt with for the proper application of this technique. The first issue is the determination of the attributes to be measured. They suggest the use of qualitative research techniques such as focus groups, and unstructured personal interviews, to identify the potentially important factors. The second issue is the separation of the importance measures and the performance measures. They assert that if both are measured together, a bias will be introduced that will render the whole exercise invalid.

For Ennew et al. (1993), the issue is to develop a better measurement for Service Quality. They state that the qualitative nature of service quality implies that cardinal scales of measurement are inappropriate, but the process of applying ordinal rankings (importance/performance) to concepts is well established as a research methodology. They argue that a comparison of mean scores on the importance of service attributes provides a straightforward measure of how well a service meets customers' needs.
In 1994 Hemmasi et al. (1994), redeveloped the Importance-Performance grid by drawing the axes based on the overall importance and performance means rather than based on the mid point of the scale. Arguably, the Hemmasi et al. (1994) grid provides a useful alternative tool for strategy development as it provides a clearer picture of the factors that are critical for resource allocation.

Research using the Importance-Performance measurement has been conducted in a number of industries including food, housing and education (Martilla and James, 1977; Joseph and Joseph, 1997) and in the banking industry (Ennew et al., 1993).

Bearing in mind all of the above and notwithstanding the widespread use of SERVQUAL, it is considered that the Hemmasi et al. (1994) method is the most appropriate way of measuring service quality in the banking industry. By using this method banking administrators can identify the potential problem areas. Administrators can also recognise the spheres that are important to their customers and make sure that the performances of those areas are to the customers' satisfaction.

\section{Methodology}

The data for this study was collected in two stages. Focus groups were conducted to identify the major themes in electronic banking, including ATM, telephone and Internet banking[1]. This provided the background information required to develop the instrument for this study. The information was obtained through two focus groups each containing approximately 20 participants each. The participants were current and recent users of electronic banking. Two independent moderators conducted the focus groups. In separate groups the participants were asked to describe what they thought a quality electronic banking system should provide. The results were recorded separately and then collated to identify commonalities among participants. On collating the results 25 common factors were identified. All groups regarded the 25 items as important elements they would look for when evaluating electronic banking. The survey for this study was based on the above factors identified by the focus group interviews.

Stage two involved distributing 440 surveys to a convenience sample of electronic banking customers from Melbourne, Australia that had used electronic banking in the previous month. A mall intercept method was used to distribute the surveys. The instrument was divided into four major 
Mathew Joseph,

Cindy McClure and

Beatriz Joseph

Service quality in the banking

sector: the impact of

technology on service delivery

International Journal of Bank

Marketing

17/4 [1999] 182-191 sections. Section one dealt with customers' perceptions of an excellent electronic banking service. Section two dealt with the ranking of the most important attributes of an electronic banking service. Section three was concerned with the consumers' perceptions of electronic banking performance and section four collected demographic information on the participants.

\section{Results}

Of the 440 surveys that were distributed for this study, 300 useable questionnaires were returned giving a response rate of 68 per cent, which was considered satisfactory for subsequent analysis. This analysis proceeded by identifying the relevant dimensions of service using the items generated from the focus groups and these were then examined in more detail for purposes of comparison between themselves and across respondents. Table I shows the rotated factor scores for the service dimensions. The eigenvalue for factor six is 1.0401 and 62.3 per cent of the total variance is attributable to the first six factors. Thus, a sixfactor model may be adequate to represent the data. The six factors identified are:

1 convenience/accuracy;

2 feedback/complaint management;

3 efficiency;

4 queue management;

5 accessibility; and

6 customisation.

A comparative analysis of the individual dimensions (grouped according to factors) results showed that the respondents do not believe that electronic banking services perform at the level that is consistent with the

\section{$\overline{\text { Table I }}$}

Rotated factor scores for a high quality electronic banking service

\section{Convenience/accuracy}

Electronic bank provides accurate records that all transactions have taken place

Electronic bank guarantees that all transactions have taken place

0.82516

Electronic bank is able to conduct transactions accurately

Electronic bank with convenient hours of operation ( 7 days, 24 hours)

Electronic banking that is easy to use

Feedback/complaint management

Electronic bank will provide customer feedback services

Electronic bank able to satisfy complaints immediately or within 24 hours

The account set up and ability to conduct a transaction is immediate

\section{Efficiency}

Efficient/no wait time

Telephone banking will connect customer immediately

All banking needs are included in menu options

Electronic bank will educate customers in how to use

Queue management

Telephone banking will provide customer friendly environment whilst waiting such as

advertising other banking services

Telephone banking will provide information about other services whilst waiting in queues $\quad 0.85648$

Telephone banking will provide customer friendly environment whilst waiting such as

music

\section{Accessibility}

ATMs will be secure, e.g. well lit at night 
Mathew Joseph,

Cindy McClure and

Beatriz Joseph

Service quality in the banking

sector: the impact of

technology on service delivery

International Journal of Bank

Marketing

17/4 [1999] 182-191 importance rating specified by customers (Table II). It is interesting to note that even though the performance of banking institutions is not perceived as being of a high standard, 52.9 per cent of the respondents reported they were satisfied with their overall electronic banking experience. It could be argued that the performance of electronic banking services falls within something which might be considered equivalent to the respondents' "zone of tolerance". This suggests that even though the respondents perceive their electronic banking services as not "quality" services, they are happy with its performance as long as certain conditions are met. It is considered that further research should be undertaken to ascertain the size and the parameters of this type of "zone of tolerance".

The ANOVA by age of the respondents yielded some statistically significant differences (Table III). The 41 yrs and above age group consider having a convenient location, a wide range of electronic services, efficiency, established customer feedback system, complaint management, special services available for the elderly and disabled and access to online directions for new users more important than their younger counterparts. The 18-40 age group felt that their

$\overline{\text { Table II }}$

Summary of means

\begin{tabular}{|c|c|c|}
\hline Attribute & $\begin{array}{l}\text { Importance } \\
\text { rating }\end{array}$ & $\begin{array}{l}\text { Performance } \\
\text { rating }\end{array}$ \\
\hline \multicolumn{3}{|l|}{ Convenience/accuracy } \\
\hline Electronic bank provides accurate records that all transactions have taken place & 4.67 & 3.95 \\
\hline Electronic bank guarantees that all transactions have taken place & 4.63 & 3.82 \\
\hline Electronic bank is able to conduct transactions accurately & 4.65 & 3.84 \\
\hline Electronic bank with convenient hours of operation ( 7 days, 24 hours) & 4.66 & 4.17 \\
\hline Electronic banking that is easy to use & 4.60 & 4.26 \\
\hline \multicolumn{3}{|l|}{ Feedback/complaint management } \\
\hline Electronic bank will provide customer feedback services & 3.97 & 3.24 \\
\hline Electronic bank able to satisfy complaints immediately or within 24 hours & 4.14 & 3.41 \\
\hline Electronic bank will help with "out of the ordinary questions" & 3.57 & 2.99 \\
\hline Electronic bank will have a professional appearance & 4.08 & 3.73 \\
\hline The account set up and ability to conduct a transaction is immediate & 3.94 & 3.47 \\
\hline \multicolumn{3}{|l|}{ Efficiency } \\
\hline Transition is efficient/no wait time & 4.54 & 3.92 \\
\hline Telephone banking will connect customer immediately & 4.47 & 4.16 \\
\hline All banking needs are included in menu options & 4.42 & 3.94 \\
\hline Electronic bank will educate customers in how to use & 4.21 & 3.66 \\
\hline Telephone banking will provide "on line" directions for new users & 4.39 & 4.45 \\
\hline Electronic bank with adequate menu options for everyday banking & 4.32 & 3.86 \\
\hline \multicolumn{3}{|l|}{ Queue management } \\
\hline $\begin{array}{l}\text { Telephone banking will provide customer friendly environment whilst waiting such } \\
\text { as advertising other banking services }\end{array}$ & 3.23 & 4.25 \\
\hline $\begin{array}{l}\text { Telephone banking will provide information about other services whilst waiting in } \\
\text { queues }\end{array}$ & 3.24 & 4.25 \\
\hline $\begin{array}{l}\text { Telephone banking will provide customer friendly environment whilst waiting such } \\
\text { as music }\end{array}$ & 3.66 & 4.39 \\
\hline \multicolumn{3}{|l|}{ Accessibility } \\
\hline ATMs will be secure, e.g. well lit at night & 4.71 & 3.38 \\
\hline Electronic bank has special services for elderly/disabled & 4.23 & 3.42 \\
\hline $\begin{array}{l}\text { Telephone banking will provide additional options, e.g. non-English speaking/sight/ } \\
\text { hearing impaired/elderly }\end{array}$ & 4.32 & 4.09 \\
\hline ATM is conveniently located & 4.66 & 3.85 \\
\hline \multicolumn{3}{|l|}{ Customisation } \\
\hline Electronic bank will be personalised (e.g. greet customer by name) & 3.20 & 2.68 \\
\hline ATM/Internet bank will acknowledge customer by name & 3.28 & 2.52 \\
\hline
\end{tabular}




Mathew Joseph,
Cindy McClure and
Beatriz Joseph
Service quality in the banking
sector: the impact of
technology on service delivery
International Journal of Bank
Marketing
$17 / 4$ [1999] 182-191

Table III

ANOVA by age

\begin{tabular}{|c|c|c|c|c|}
\hline Attribute & $\begin{array}{l}\text { Importance } \\
\text { means }\end{array}$ & $\begin{array}{c}F \\
\text { value }\end{array}$ & $\begin{array}{l}\text { Performance } \\
\text { means }\end{array}$ & $\begin{array}{c}F \\
\text { value }\end{array}$ \\
\hline
\end{tabular}

Convenience/accuracy

Electronic bank provides accurate records that all

transactions have taken place:

17 years and under

4.58

18-28 years

29-40 years

41-64 years

65 years and above

Electronic bank guarantees that all transactions have taken place

17 years and under

18-28 years

29-40 years

41-64 years

65 years and above

Electronic bank is able to conduct transactions accurately

17 years and under

18-28 years

29-40 years

41-64 years

65 years and above

4.57

4.66

4.61

4.75

0.382

4.25

4.31

4.07

4.27

4.42

4.25

4.64

4.76

4.69

4.62

3.75

4.41

4.44

4.45

4.87

Electronic bank with convenient hours of operation ( 7 days, 24 hours)

17 years and under

18-28 years

29-40 years

41-64 years

65 years and above

Electronic banking that is easy to use

17 years and under

18-28 years

29-40 years

41-64 years

65 years and above

4.00

4.53

4.49

4.71

4.75

4.08

4.12

4.27

4.33

4.62

2.420

3.75

4.15

4.15

4.30

4.12

3.384

4.00

4.01

3.81

3.86

3.87

$3.241 \quad 3.75$

3.93

3.77

3.98

4.25

$1.342 \quad 3.83$

3.54

3.27

3.77

4.25

Feedback/complaint management

Electronic bank will provide customer feedback services

17 years and under

18-28 years

4.16

0.578

3.91

3.88

29-40 years

41-64 years

65 years and above

3.89

4.03

4.25

3.36

3.23

3.87

3.75

within 24 hours

17 years and under

29-40 years

41-64 years

65 years and above

4.64

4.72

5.00

4.03

4.12

Electronic bank will help with "out of the ordinary questions"

17 years and under

18-28 years

29-40 years

41-64 years

65 years and above

4.41

1.546

3.58

3.83

3.55

4.03

4.00

Electronic bank will have a professional appearance

17 years and under

4.52

4.71

5.00

3.91

3.93

3.77

4.13

4.12
29-40 years

65 years and above
4.65

4.74

5.00
1.429

1.113

0.548 


\begin{tabular}{|c|c|c|c|c|c|}
\hline \multirow{3}{*}{$\begin{array}{l}\text { Mathew Joseph, } \\
\text { Cindy McClure and } \\
\text { Beatriz Joseph } \\
\text { Service quality in the banking } \\
\text { sector: the impact of } \\
\text { technology on service delivery }\end{array}$} & \multicolumn{5}{|l|}{ Table III } \\
\hline & Attribute & $\begin{array}{l}\text { Importance } \\
\text { means }\end{array}$ & $\begin{array}{c}\mathbf{F} \\
\text { value }\end{array}$ & $\begin{array}{c}\text { Performance } \\
\text { means }\end{array}$ & $\begin{array}{c}\mathbf{F} \\
\text { value }\end{array}$ \\
\hline & \multicolumn{5}{|l|}{$\begin{array}{l}\text { The account set up and ability to conduct a transaction is } \\
\text { immediate }\end{array}$} \\
\hline \multirow{53}{*}{$\begin{array}{l}\text { International Journal of Bank } \\
\text { Marketing } \\
17 / 4 \text { [1999] 182-191 } \\
\end{array}$} & 17 years and under & 3.41 & \multirow[t]{4}{*}{0.953} & 3.08 & \multirow[t]{4}{*}{1.672} \\
\hline & 18-28 years & 3.11 & & 2.62 & \\
\hline & $\begin{array}{l}29-40 \text { years } \\
41-64 \text { years }\end{array}$ & $\begin{array}{l}3.20 \\
3.37\end{array}$ & & $\begin{array}{l}2.38 \\
3.06\end{array}$ & \\
\hline & 65 years and above & 3.25 & & 2.50 & \\
\hline & \multicolumn{5}{|l|}{ Efficiency } \\
\hline & \multicolumn{5}{|l|}{ Transaction is efficient/no wait time } \\
\hline & 17 years and under & 3.58 & \multirow[t]{5}{*}{1.805} & 3.58 & \multirow[t]{5}{*}{1.802} \\
\hline & 18-28 years & 3.48 & & 2.90 & \\
\hline & $29-40$ years & 3.47 & & 2.83 & \\
\hline & 41-64 years & 3.84 & & 3.14 & \\
\hline & 65 years and above & 4.00 & & 3.87 & \\
\hline & \multicolumn{5}{|l|}{ Telephone banking will connect customer immediately } \\
\hline & 17 years and under & 4.08 & \multirow[t]{6}{*}{1.241} & 3.83 & \multirow[t]{6}{*}{0.720} \\
\hline & $18-28$ years & 4.27 & & 3.85 & \\
\hline & $29-40$ years & 4.37 & & 3.70 & \\
\hline & 41-64 years & 4.37 & & 3.98 & \\
\hline & 65 years and above & 4.62 & & 4.00 & \\
\hline & All banking needs are included in menu options & & & & \\
\hline & 17 years and under & 4.33 & \multirow[t]{5}{*}{4.54} & 3.08 & \multirow[t]{5}{*}{0.848} \\
\hline & $18-28$ years & 4.08 & & 3.39 & \\
\hline & $29-40$ years & 4.18 & & 3.28 & \\
\hline & 41-64 years & 4.54 & & 3.70 & \\
\hline & 65 years and above & 4.87 & & 3.25 & \\
\hline & \multicolumn{5}{|l|}{ Electronic bank will educate customers in how to use } \\
\hline & 17 years and under & 3.75 & \multirow[t]{5}{*}{2.85} & 3.33 & \multirow[t]{5}{*}{1.238} \\
\hline & $18-28$ years & 4.06 & & 3.38 & \\
\hline & $29-40$ years & 4.06 & & 3.15 & \\
\hline & 41-64 years & 4.47 & & 3.66 & \\
\hline & 65 years and above & 4.37 & & 4.00 & \\
\hline & $\begin{array}{l}\text { Telephone banking will provide "on line" directions for new } \\
\text { users }\end{array}$ & & & & \\
\hline & 17 years and under & 3.83 & 2.690 & 3.91 & 1.178 \\
\hline & $18-28$ years & 3.89 & & 3.20 & \\
\hline & $29-40$ years & 3.89 & & 3.08 & \\
\hline & 41-64 years & 4.23 & & 3.25 & \\
\hline & 65 years and above & 4.37 & & 3.75 & \\
\hline & $\begin{array}{l}\text { Electronic bank with adequate menu options for everyday } \\
\text { banking }\end{array}$ & & & & \\
\hline & 17 years and under & 3.91 & 0.900 & 3.75 & 0.162 \\
\hline & 18-28 years & 4.06 & & 3.72 & \\
\hline & $29-40$ years & 4.01 & & 3.66 & \\
\hline & 41-64 years & 4.23 & & 3.79 & \\
\hline & 65 years and above & 4.12 & & 3.75 & \\
\hline & $\begin{array}{l}\text { Queue management } \\
\text { Telephone banking will provide customer friendly } \\
\text { environment whilst waiting such as advertising other } \\
\text { banking services }\end{array}$ & & & & \\
\hline & 17 years and under & 4.50 & 0.561 & 3.83 & 0.369 \\
\hline & 18-28 years & 4.65 & & 3.83 & \\
\hline & $29-40$ years & 4.67 & & 3.77 & \\
\hline & 41-64 years & 4.67 & & 3.93 & \\
\hline & 65 years and above & 4.87 & & 4.12 & \\
\hline & $\begin{array}{l}\text { Telephone banking will provide information about other } \\
\text { services whilst waiting in queues }\end{array}$ & & & & \\
\hline & 17 years and under & 4.66 & 2.093 & 3.58 & 0.533 \\
\hline & 18-28 years & 4.68 & & 3.34 & \\
\hline & 29-40 years & 4.61 & & 3.40 & \\
\hline & 41-64 years & 4.86 & & 3.35 & \\
\hline & 65 years and above & 5.00 & & 3.87 & \\
\hline
\end{tabular}




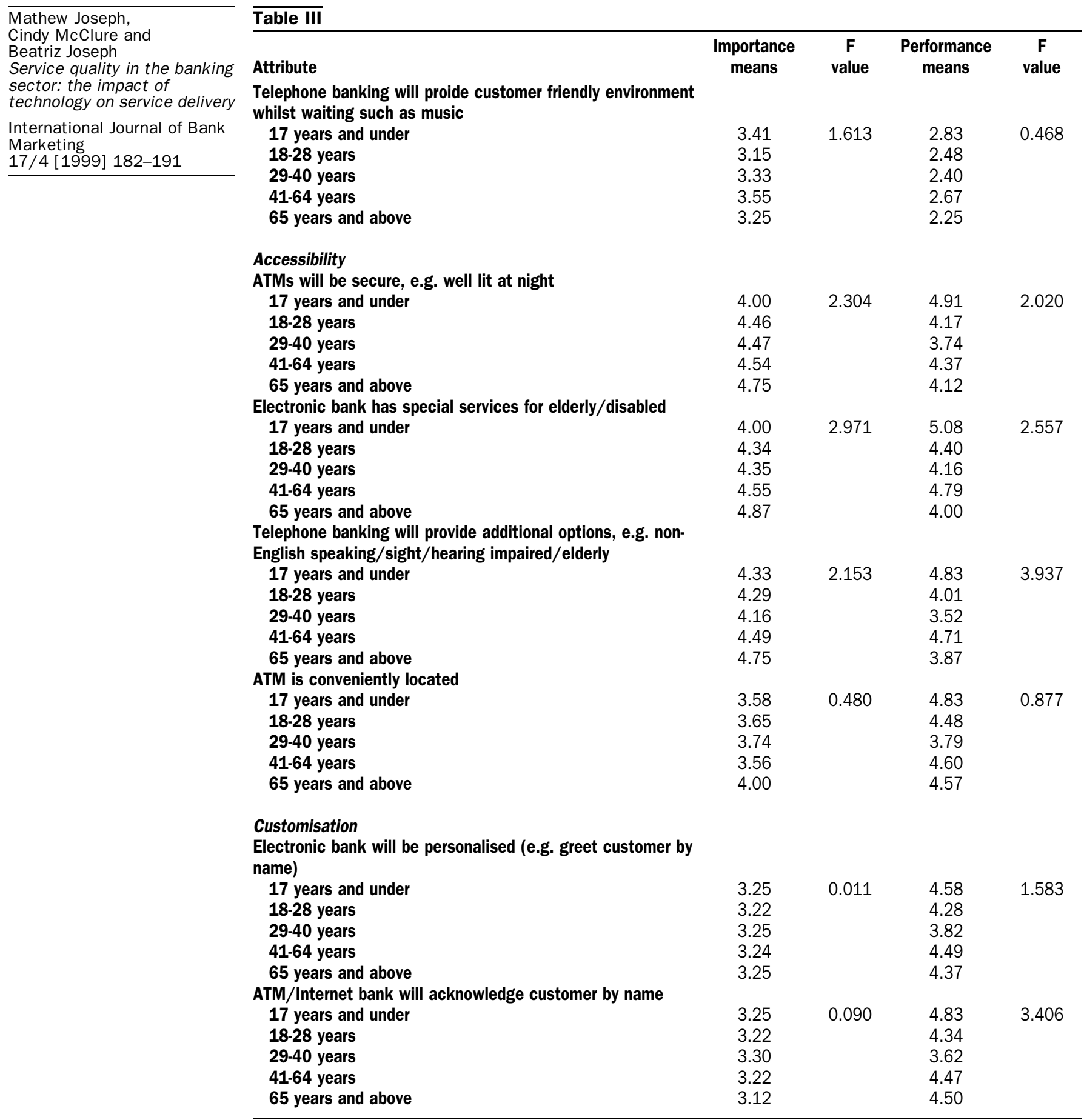

banking institution had an average performance regarding how quickly they can get access to electronic banking and the quality of the educational brochures provided to new users.

Looking at the results using the Importance-Performance Grid (Figure 1), it is evident that banking institutions need to improve their customer-perceived service quality. Only two of the five categories (convenience/accuracy and efficiency) fall in the "keep up the good work" quadrant. There is also evidence that indicates that banking administrators need to revise their resource allocation as two categories (customise and feedback/complaints) fall in the "low priority" quadrant and one (queue management) in the "possible overkill" quadrant.

Respondents were asked to state what was the best and worst aspects of electronic banking. Of those surveyed, 51.9 per cent stated that convenience was the best aspect, 
Mathew Joseph,

Cindy McClure and

Beatriz Joseph

Service quality in the banking

sector: the impact of

technology on service delivery

International Journal of Bank

Marketing

17/4 [1999] 182-191

Figure 1

The Importance-Performance grid

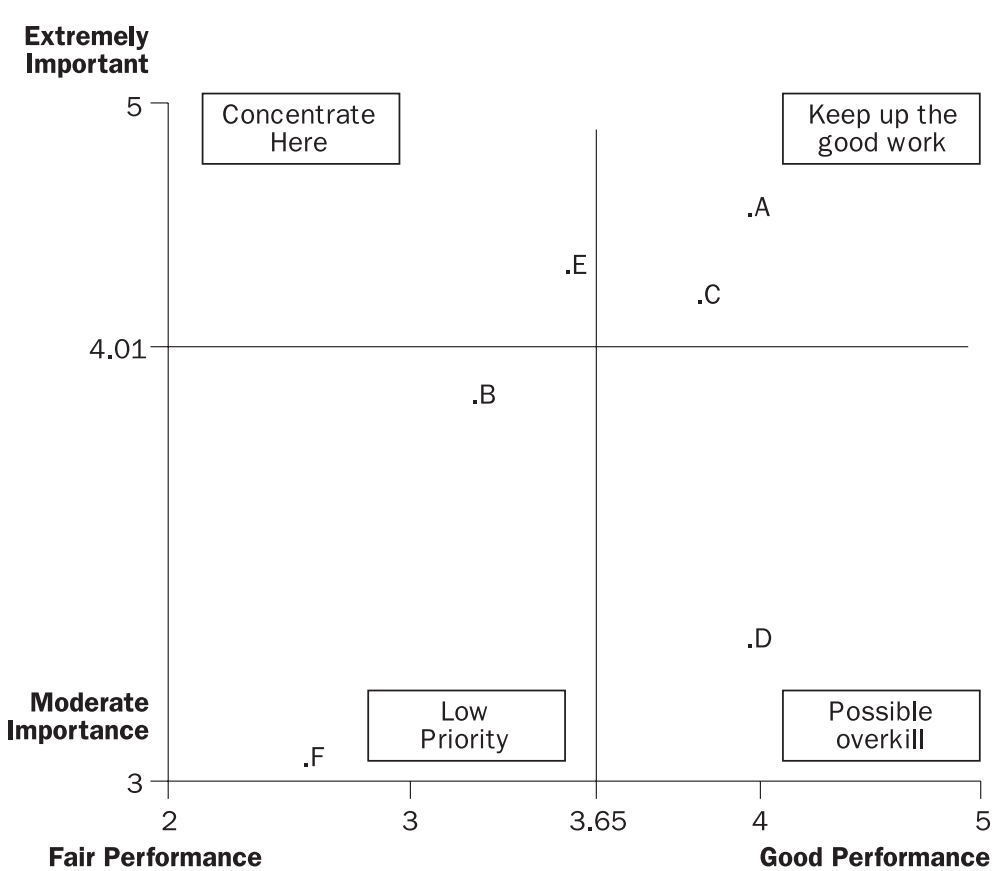

Key

$\mathrm{A}=$ Convenience $/$ Accuracy

$\mathrm{B}=$ Feedback/Complaints

$\mathrm{C}=$ Efficiency

$\mathrm{D}=$ Queue Mgmt

$\mathrm{E}=$ Accessibility

$\mathrm{F}=$ Customised with 52.9 per cent noting that waiting time was the worst. When asked what they would most like to change about electronic banking, 22 per cent wanted changes made to the ATM features and another 22 per cent wanted more security across electronic banking services.

\section{Conclusions and strategic implications}

The analysis from the gap scores and the Importance-Performance grid displays a perceptual problem when the sample indicates poor performance of electronic banking facilities compared with an ideal banking service. The Importance-Performance grid banking need to concentrate their efforts in several areas:

- Banks should provide statements of all transactions that have been conducted electronically. This will allow consumers to verify accuracy of all transactions including transaction confirmation.

- Banks should find ways of making their electronic services more accessible. Installing more ATMs and EFTPOS outlets is an issue, which customers consider very important and which is not being addressed to the customers' satisfaction.

- Banks should also provide customers with a toll free number. This number could suggests that banks providing electronic handle customer complaints and general feedback about the electronic banking services. This would not only provide a service to consumers that is free, but also provide the banks with valuable trends for future development on electronic services.

- Banks should improve the security of ATMs by making them well lit at night.

- Banks should develop their electronic facilities to cater for the elderly and disabled. ATMs that read out the keys pressed would aid the sight impaired as well as lowering the height of the ATM screens making the service available to people in wheel chairs.

- Banking administrators should revise their resource allocation in light of the importance/performance findings. Queue management is in the "possible overkill" quadrant, which means that management thinks it is more important than customers do. Banks would be better served by using some of their resources on addressing the issue of "accessibility".

Customer feedback is an established concept of strategic planning (Lovelock, 1991). It is therefore recommended that the performance of banking institutions be monitored on a regular basis. This is important as isolated monitoring could give "snapshots" only and not accurately depict trends.

\section{Suggestions for further research}

- Determine the parameters of the customers' "zone of tolerance". This is important because managers need to know at what point customers cease to be satisfied with the core service they are receiving. Due to resource restrictions, in some instances it is not possible for institutions to provide everything that customers want. Knowledge of the zone of tolerance allows institutions to allocate resources accordingly.

- Ascertain which are the determinants of service quality based on the different types of technology. This study has taken a generalised perspective on electronic banking, however the authors acknowledge the effect the different technologies might have on perceptions of quality.

- Another area of further research is the replication of this study in other countries. This will provide insights relative to the impact of culture on the evaluation of service quality in electronic banking. This is considered an important issue due to the nature of the global market economy in which banking institutions operate. 
Mathew Joseph,

Cindy McClure and

Beatriz Joseph

Service quality in the banking

sector: the impact of

technology on service delivery

International Journal of Bank

Marketing

17/4 [1999] 182-191

\section{Note}

1 While recognising the differences in these technologies, the current study was concerned with general perceptions of electronic banking as a new delivery system, irrespective of its specific technological form.

\section{References}

Australian Coalition of Service Industries Annual Review (1997a), Spectator or Serious Player? Competitiveness of Australia's Information Industries, p. 20.

Australian Coalition of Service Industries Annual Review, (1997b), The Global Information Economy: The Way Ahead, p. 21.

Bateson, J.E. (1984), Perceived Control and the Service Encounter.

Bradley, S. (1993), "The role of IT networking in sustaining competitive advantage", in Bradley, S., Hausman, J. and Nolan, R. (Eds), Globalising Technology and Competition, Harvard Business School Press, Boston, MA, pp. 113-42.

Carman, J. (1990), "Consumer perceptions of service quality: an assessment of the SERVQUAL dimensions", Journal of Retailing, Vol. 66 No. 1, Spring, pp. 33-55.

Choice Magazine (1998a), Australian Consumers' Association, "What's wrong with your bank?," March, pp. 6-11.

Choice Magazine (1998b), Australian Consumers' Association, "Pushbutton banking," March, pp. 18-21.

Cowels, D. and Crosby, L. (1990), "Consumer acceptance of interactive media," The Services Industries Journal, Vol. 10 No. 3, pp. 521-40.

Cronin, J. and Taylor, S. (1992), "Measuring service quality: a reexamination and extension", Journal of Marketing, Vol. 56, July, pp. 55-68.

Cronin, J. and Taylor, S. (1994), "SERVPERF versus SERVQUAL: reconciling performancebased and perceptions-minus-expectations measurement of service quality", Journal of Marketing, Vol. 58, January, pp. 125-31.

Dabholkar, P. (1994), "Technology based service delivery", Advances in Services Marketing and Management, Vol. 3, pp. 241-71.

Dabholkar, P. (1996), "Consumer evaluations of new technology-based self-service options: an investigation of alternative models of service quality”, International Journal of Research in Marketing, Vol. 3, pp. 29-51.

Ennew, C.T., Reed, G.V. and Binks, M.R. (1993), "Importance-performance analysis and the measurement of service quality", European Journal of Marketing, Vol. 27 No. 2, pp. 59-70.

Gilbert, A. (1997), "Globalisation knowledge and technology. What the revolution means for education”, RJ White Service Lecture, ACSI Annual General Meeting, 7 December, NSW. Gummeson, E. (1991), Qualitative Methods in Management Research, Sage Publications.

Hemmasi, M., Graf, L. and Neilson, W. (1992), "Triggering organisational change: application of importance-satisfaction analysis", Creativity and Innovation Management, Vol. 1 No. 4, December, pp. 240-4.

Hemmasi, M., Strong, K. and Taylor, S. (1994), "Measuring service quality for planning and analysis in service firms", Journal of Applied Business Research, Vol. 10 No. 4, pp. 24-34.

Joseph, M. and Joseph, B. (1997), "Service quality in education: a student perspective", Quality Assurance in Education, Vol. 5 No. 1, pp. 15-21.

Kelley, S. (1989), "Efficiency in service delivery: technology or humanistic approaches?", The Journal of Services Marketing, Vol. 3 No. 3, Summer, pp. 43-51.

Loudon, D. and Della Bitta, A. (1988), Consumer Behaviour: Concepts and Applications, 3rd Edition, McGraw-Hill International, Singapore.

Lovelock, C. (1991), Service Marketing, PrenticeHall Inc., Englewood Cliffs, NJ.

Martilia, J. and James, J. (1977), "Importanceperformance analysis”, Journal of Marketing, Vol. 41, January, pp. 77-9.

Ortinau, D., Bush, A., Bush, R. and Twible, J. (1989), "The use of importance-performance analysis for improving the quality of marketing education: interpreting faculty-course evaluations," Journal of Marketing Education, Summer, pp. 78-86.

Parasuraman, A., Zeithaml, V. and Berry, L. (1985), "A conceptual model of service quality and its implications for future research", Journal of Marketing, Fall, Vol. 49, pp. 41-50.

Parasuraman, A., Zeithaml, V. and Berry, L. (1988), "SERVQUAL: a multiple-item scale for measuring consumer perceptions of service quality", Journal of Retailing, Vol. 64, Spring, pp. $12-40$.

Quinn, B. (1996), "The productivity paradox is false: Information technology improves service performance," Advances in Services Marketing and Management, Vol. 5, pp. 16-21.

Teas, K. (1994), "Expectations as a comparison standard in measuring service quality: an assessment of a reassessment", Journal of Marketing, Vol. 58, pp. 132-9.

Teas, K. (1993), "Expectations, performance evaluation and consumers' perception of quality", Journal of Marketing, Vol. 57, pp. 18-34.

Voice + The European Magazine for Applications of Computer Telephony, (1997) (March), p. 62.

Weatherall, D.J., Ledingham, J.G.G. and Worrell, D.A. (1984), Oxford Textbook of Medicine, Oxford University Press, Oxford. 